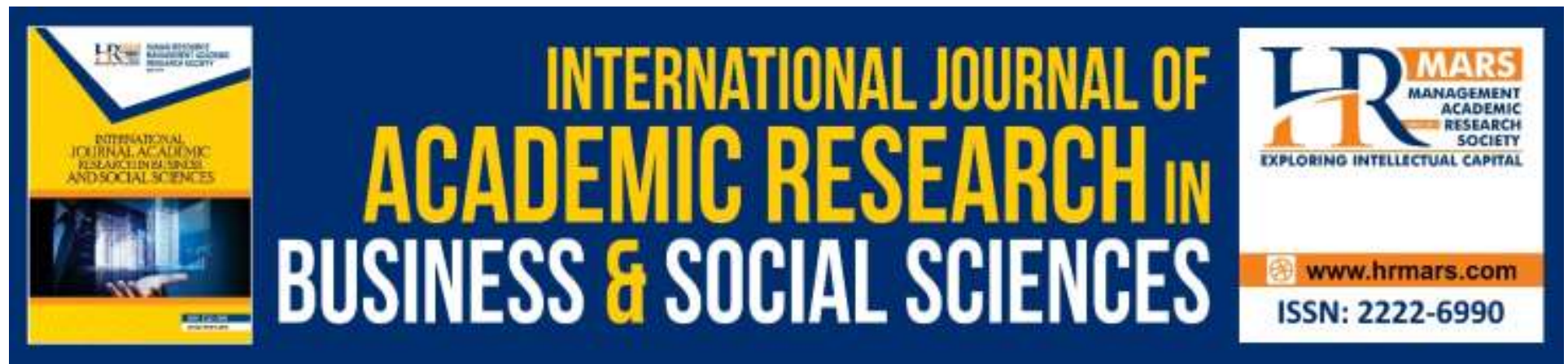

\title{
Management of Accounting for Business Zakat Practices in Malaysia: A Closer Look
}

Mohd Rizuan Abdul Kadir, Abdul Aziz Abdullah

To Link this Article: http://dx.doi.org/10.6007/IJARBSS/v9-i11/6608

DOI: 10.6007/IJARBSS/v9-i11/6608

Received: 09 October 2019, Revised: 29 October 2019, Accepted: 13 November 2019

Published Online: 29 November 2019

In-Text Citation: (Kadir \& Abdullah, 2019)

To Cite this Article: Kadir, M. R. A., Abdullah, A. Z. (2019). Management of Accounting for Business Zakat Practices in Malaysia: A Closer Look. International Journal of Academic Research in Business and Social Sciences, 9(11), 894-906.

Copyright: (C) 2019 The Author(s)

Published by Human Resource Management Academic Research Society (www.hrmars.com) This article is published under the Creative Commons Attribution (CC BY 4.0) license. Anyone may reproduce, distribute, translate and create derivative works of this article (for both commercial and non-commercial purposes), subject to full attribution to the original publication and authors. The full terms of this license may be seen at: http://creativecommons.org/licences/by/4.0/legalcode

Vol. 9, No. 11, 2019, Pg. 894 - 906

Full Terms \& Conditions of access and use can be found at http://hrmars.com/index.php/pages/detail/publication-ethics 


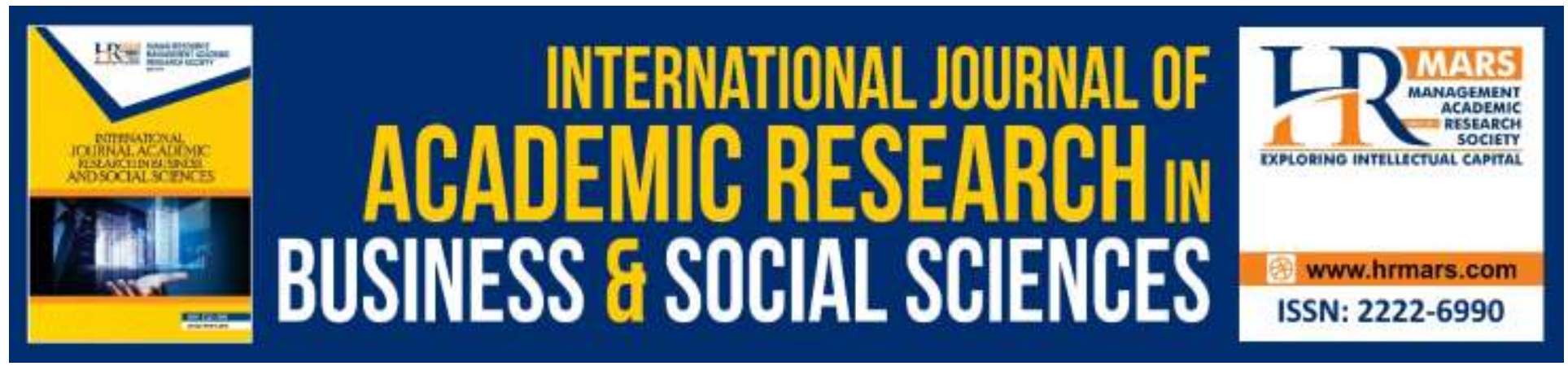

\title{
Management of Accounting for Business Zakat Practices in Malaysia: A Closer Look
}

\author{
Mohd Rizuan Abdul Kadir \\ Universiti Tenaga Nasional, Bandar Muadzam Shah, Pahang, Malaysia. \\ Email: mrizuan@uniten.edu.my \\ Abdul Aziz Abdullah \\ Universiti Sultan Zainal Abidin, Gong Badak, Kuala Terengganu, Malaysia. \\ Email: abdulazizum@gmail.com
}

\begin{abstract}
Zakat is one of the pillars in Islam. In Malaysia, zakat has been practiced since the arrival of Islam. And today, the practices have been well structured through the establishment of zakat institutions, wider coverage on zakatable assets and proper determination of computation techniques. This has resulted to an increase in the zakat collection to billions of ringgit per-year. This paper is designed to explore the evolution of business zakat practices in Malaysia, includes the use of accounting to facilitate business zakat computation. It will discuss on how the computation of business zakat being structured in Malaysia, the acceptance of accounting towards the practice of business zakat and recent development to strengthen the practice of business zakat. Currently, it can be concluded that the efforts to use accounting to facilitate the business zakat computation has been started, but yet being finished. Thus, this paper suggests a post-structural study to be conducted to review and enhance the existing structure of both, the accounting and zakat practices. The Shariah conditions imposed to zakatable business assets need to be harmonised with accounting principles, for the sake of both practices. This is to ensure that the accounting disclosure can be used as the basis in determining zakatable business assets.
\end{abstract}

Keywords: Accounting for Zakat, Business Zakat Computation, Business Zakat Administration

\section{Early History of Zakat Practices in Malaysia}

The zakat practiced in Malaysia started with the arrival of Islam in the Malay peninsula (Wahid \& Kader, 2008). Islam was spread by the Persian and Arab Muslims as early as in the seventh century (Means, 2006). However, the mass conversion to Islam took place in the thirteen 
century, as a result of aggressive campaign from the Muslim Sufis' who came from India (Means, 2006). Zakat, being one of Islamic pillars, has been embedded in Islamic teaching, eventually leading into mass practice by the Muslims.

During pre-colonial period, the zakat system in peninsular Malaya was in the form of informal system managed by a person called ustaz or amil (Rahman, \& Najib, 2012; Wahid et al., 2008). The Ustaz or amil was entrusted by the community to collect and distribute the zakat collection. At that time, the zakat collection from the community was very small and rather limited. This collection was only seasonal in nature, mainly at the end of Ramadan (the fasting month, nine month of Hijrah calendar) until before the prayer of aldilfitri (Muslim celebration after fasting month), and during the paddy harvest seasons (Rahman et al., 2012).

During the British colonial era, they brought secularism ideology that separated the religious matters from state administration (Means, 2006). Back then, zakat was seen by the colonials as merely an ibadah (worship) of the Muslims (Ibrahim, 1997) and confined only to the Malays. Moreover, the collection at that time was not significant enough to contribute to the nation's development. In a nutshell, even then, Malay and Islam cannot be separated, as the Malays presume 'Islam is Malay' and 'Malay is Islam' (Means, 2006). Thus, zakat was placed under the Majlis Agama Islam Negeri (MAIN) (The State Islamic Religious Council - SIRC) to be administered by the state Rulers. All the zakat collected were administered by SIRC to be used in administrating the Islamic affairs (Wahid et al., 2008).

Even after independence, the zakat administration in Malaysia was still considered as a religious matter, to be administered by the state Rulers. The Malaysian Constitution, article 3(2) provided that, "in every State other than States not having a Ruler the position of the Ruler as the Head of the religion of Islam in his state in the manner and to the extent acknowledged and declared by the Constitution, all rights, privileges, prerogatives and powers enjoyed by him as Head of that religion." And the detailed about the Islamic fund raised by the states in article 97(3), that "any Zakat, Fitrah, Bait-ul-Mal or similar Islamic religious revenue is raised, it shall be paid into a separate fund and shall not be paid out except under the authority of State law ...".

The power of the state Rulers regarding the religious matters is absolute without interference from the federal government as stated in Article 150 (6A), "shall not extend the powers of Parliament with respect to any matter of Islamic law or the custom of the Malays....". In Malaysia, the Federal government has no authority to interfere in state religious administration, including in the zakat affairs (Bahrom \& Yaakub, 2007; Hussaini, Bakar, Yusuf, 2018 ).

As such, SIRC becomes the sole entrusted bodies by the state Rulers' to collect the zakat dues. This is consistent with Islamic practices that the obligation to collect the zakat dues is the responsibility of the authority or government (Bahrom \& Yaakub, 2007). As stated in the Quran, God says, "Take Sadaqah (obligatory alms) out of their wealth through which you may cleanse and purify them, and pray for them..." (Quran 9:10). From hadith reported by Bukhari from Ibn "Abbas, "take zakat from the rich among them, and give it to the poor among them". Subsequently from Abu Hurairah r.a.; "Rasulullah had sent Umar Ibn Khattab to collect the zakat". 
Due to the importance of zakat practices, especially in the development of the Malaysian economy of the Muslim ummah, the zakat authorities at that time recognised the needs for extensive changes in zakat administration, especially on collection matter (Rahman et al., 2012). This has led to the modernisation in zakat administration, which started in early 1990s.

\section{Modernisation in Zakat Administration}

Modernisation in zakat was started in the early 1990s, whereby the administrations started to be privatised (Rahman et al., 2012; Rais, 2013). Zakat administration has been restructured to bring back their original function to enhance the economic status of the Muslims (Bahrom \& Yaakub, 2007). In 1991, the State Islamic Religious Council (SIRC) of Wilayah Persekutuan developed the first Zakat Collection Centre namely Pusat Pungutan Zakat Wilayah Persekutuan (PPZ WP) to deal with zakat collection and its distribution. Since then, all the states in Malaysia have started to introduce their collection centre under different names.

The state of Selangor privatised their zakat collection in 1994 under the name 'Pusat Zakat Selangor (PZS)', Pulau Pinang in 1994 using the name of 'Pusat Urus Zakat Pulau Pinang (PUZ PP)', Pahang in 1995 using the name of 'Pusat Kutipan Zakat Pahang (PKZP)' and Negeri Sembilan in 1998 by using the name of 'Pusat Zakat Negeri Sembilan (PZNS)'. Currently all states in Malaysia have institutionalised their zakat collection centres, the bodies that act as subsidiary under the SIRC.

The purpose of the privatising zakat collection is to maximise the efficiency of zakat collection (Rahman et al., 2012; Mansor et al., 2018). Through this approach where the technologies have been brought in, more zakat collection centres have been established, and corporate working ecosystem have been set up. These had led to the encouragement of innovation, creativity, proactive and expedite the delivery system in zakat management (Rahman et al., 2012). The mode of payment becomes easier through available counters, salary deduction schemes, money post orders, mobile zakat counters and with the usage of computer, operating online, resulted in the increase in zakat collection (Ismail \& Azura, 2006).

The changes made through the privatisation of zakat collection centre have shown positive effect. There has been an increased in the amount of zakat collected by each state (Sanep \& Hairunnizam et al., 2006) and has kept increasing over the years.

In 1992, the $31^{\text {st }}$ discussion of the National Fatwa Committee about "zakat on companies" (Zakat ke atas Syarikat) was conducted (E-Fatwa, 2009). The output of this discussion was another cornerstone towards a development of zakat collection in Malaysia. The National Fatwa Committee has agreed that the zakat on business are compulsory if the business has fulfilled all zakat conditions (E-Fatwa, 2009); (a) business owned by Muslims, (b) owned by independent Muslim (this item has lost its relevance), (c) complete ownership, (d) nisab (reach minimum level), (e) haul (one year qamariah / 354.3 days), and (f) zakatable at $2.5 \%$.

The fatwa was made based on a verse in the Quran, as God says, " $O$ you who believe, spend of the good things you have earned, and of what We have brought forth for you from the earth, and do not opt for a bad thing, spending only from it, while you are not going to accept it (if such 
a thing is offered to you), unless you close your eyes to it, and know well that Allah is AllIndependent, Ever-Praised" (Quran 2:267).

The Fatwa Committee also agreed that if the business is shared between Muslims and the non-Muslim, it is compulsory for the Muslim partners to pay zakat based on their portion. This is based on a hadith, reported by Saad bin Abi Waqqas, the Prophet Muhammad (PBUH) said, "The separate assets should not be joined together not the joint assets should be separated to avoid zakat and whatever that belongs to two persons, they must settle their account in proportion to their ownership" (Abu-Ubayd, 2007).

Another discussion was conducted on the $10^{\text {th }}$ May 2001 by the National Fatwa Committee with regard to the zakat on companies that have mixed ownership, both the Muslims and nonMuslims. During this discussion, the committee had agreed that the zakat is imposed only on the portion of Muslim shares (E-Fatwa, 2009).

With this fatwa, it is confirmed that a number of individuals (both muslims and non muslims) who jointly hold their assets are considered as an entity, non-separated from each other. Their joint assets are zakatable, but are limited to the portion owned by the Muslims only. Payment of zakat is at the business level, on behalf of their shareholders. However, if the business does not pay zakat, then the shareholders have to pay zakat on their own (Ahmad, 2006; E-Fatwa, 2009).

The fatwa has made it clear on the business zakat obligation. On the business assets that are subject to zakat, the jurists have agreed that it should be based on urud al-tijarah (AbuUbayd, 2007; Wafa, 2006b). Here come the complication as the term al-tijarah is very subjective. On the early practices of business zakat in Malaysia, there was confusion on how to determine the urud al-tijarah (Adnan \& Teh, 2013) as there was no single approach in practise at that time.

Therefore, there is a need for a structural approach in determining the term al-tijarah for business zakat computation.

\section{Structural Approach in Business Zakat Computation}

Structural approach can be defined as the way something is built or organised. In 1990s, there was no single approach on how to calculate the business zakat. Since the zakat administration is controlled by individual states, under the rule of the Malay Rulers, there were diverse practices on business zakat computation (Rahman et al., 2012; Ahmad et al., 2013; Hamat, 2011; Norita \& Salleh, 2005). Accordingly, it was based on the individual state 'will' (Abu Bakar, 2007). This leads to the needs of structural practices, whereby a standardised approach is used by all the zakat authorities to calculate the business zakat.

Although there is a clear fatwa on the business zakat, another issue was raised; how to determine the zakat for business wealth. The determination on business zakat is stated in a Hadith, from the narration of Abu Daud, as reported by Samurah bin Jundub that, "the Prophet Muhammad (PBUH) used to order us to pay al sadaqah out of what we have for sale (al-tijarah)." (Al Qaradawi, 2011; Ibn Rushd, 1994; Lembaga Zakat Selangor, 2007). However, the early Muslims scholars had different opinions regarding the meaning of al-tijarah (Ahmad et al., 2013). 
The different of opinion was due to the dispute about the imposition of zakat through analogy, and over the authenticity of the tradition of Samurah bin Jundub (Ibn-Rushd, 1994).

The confusion on how to apply al-tijarah also happen in Malaysia (Ahmad et al., 2013). For example, Norita \& Salleh (2005) stated that there were five methods available for calculating business zakat in Malaysia; net assets (working capital), net equity (growth model), net profit after sales, combined method and dividend method. On the other hand, Zahri (2011) mentioned that there are three methods that were used by the states' zakat collection centre to calculate the business zakat instead; the current assets, the net working capital (current assets minus with current liabilities) and the adjusted working capital.

The confusion and divergence in the practices of business zakat computation indicates that there is a need for proper structure on business zakat computation. This had led to the establishment of working group to discuss about the method for business zakat computation. This group was initiated by Pusat Zakat Selangor (currently known as Lembaga Zakat Selangor (LZS)) in 1999. The working group consisted of group of scholars coming from diverse backgrounds in Shariah, economic and accounting. Accordingly, they are Dr. Zainuddin Jaafar, Dr. Abdullah Ibrahim, Dr. Hailani Muji Tahir, Dr. Mohd Bakar Daud, Dr. Mohd Mokhtar Safie, Nasir Hj. Masud, Mohd Salleh Ahmad, Dr. Syed Musa al-Habsi, Hassan Hj Ahmad, Abdul Majid Omar and Dato Syed Mohd Ghazali Wafa Syed Adwam Wafa (Hamat, 2007).

This effort was supported by Secretariat Pusat Zakat Negeri (SPZN), a centre comprising a representative from the state's zakat authorities. The purpose of SPZA is to harmonise the diverse practices on zakat administration in Malaysia. Through the series of discussions, two interpretations for business zakat computation were proposed, known as the working capital method and the net growth method. In 2001, these methods being recognised by Jabatan Kemajuan Islam Malaysia (JAKIM). The working guide to use these methods is published by JAKIM in the book title, 'Zakat Management Guide'. One of the objectives of publishing this book was to promote standardisation practices on business zakat computation in Malaysia.

Currently, it is understood that all the states in Malaysia have agreed to use the net working capital method as the basis to determine the business zakat. Meanwhile, financial institutions use the net growth method which is more suitable to the nature of their business. From the discussion, it can be said that the development of zakat computation methods was the first effort towards the formulation of structural approach for the business zakat computation in Malaysia.

The structure formulated has gained further mileage when it was recognised by the Malaysian Accounting Standard Board (MASB), a body responsible in issuing accounting standard in Malaysia, as the method to be used in determining the business zakat for companies in Malaysia.

\section{Accounting for Zakat on Business}

In 2005, another remarkable event on business zakat development in Malaysia took place. With the initiative of the then Prime Minister, YAB Dato' Seri Abdullah Bin Hj. Ahmad Badawi, business zakat was allowed to be deducted as expenses in the computation of business income, under Section $44(11 \mathrm{~A})$, at the maximum of $2.5 \%$ of aggregate income. With this provision, the 
role of zakat as part of Malaysian fiscal system is recognized by the government (Bakar \& Rahman, 2007). With a $2.5 \%$ deduction from aggregate income, at least some of the compulsory burdens (the double burden of taxation and zakat), which is imposed to the Muslim entrepreneurs can be released (Mahamood, 2007).

From 2005 onwards, we have seen a significant increase in the business zakat collection in Malaysia. For example, in the state of Selangor, the business zakat collection for 2005 increased from RM20,319,330 to RM27,547,360.90, an increment of 35\%, and Wilayah Persekutuan has seen the increase from RM20,123,320.27 to RM22,790,507.33, an increment of $13 \%$.

Owning to that situation, the MASB has recognized the needs of proper accounting treatment and disclosure for business zakat (MASB, 2006). The MASB, through the Islamic working group which is established to deal with Islamic based standards, formed a working team to study the accounting treatment and disclosure for business zakat. The team included Syed Mohd Ghazali Wafa Syed Adwam Wafa, a scholar with a background in accounting, zakat and Islamic finance. He also involved in developing the business zakat computation structures, and the zakat guide book published by JAKIM in 2001.

As a result of zakat' working group discussion held in 2006, the first Malaysian locally developed accounting pronouncement was issued, namely the Accounting for Zakat on Business (MASB TR i-1). This document was issued as a technical release (TR), which performs as a technical guideline in dealing with zakat accounting treatment and disclosure (Abu Bakar, 2007; Ibrahim, Kadir \& Aziz, 2012). The accounting pronouncement was took effect from 1 July 2006. Among the reasons given for the issuance of accounting pronouncement for zakat on business are:

a. There is a lack of guidance on the recognition, measurement, and presentation and disclosure of zakat by entities that pay zakat, and an accounting pronouncement would improve the comparability of reported financial information on zakat;

b. The issuance of an accounting pronouncement is welcomed by all the 14 zakat authorities in Malaysia for a uniform accounting pronouncement on zakat for business to streamline the accounting treatment of zakat; and

c. Recently approved tax incentives for zakat on business may lead to more entities to pay zakat. With effect from the year of assessment 2005, zakat paid by the entity was eligible to claim deduction with the limit of $2.5 \%$ of entity's aggregate income. Thus, an accounting pronouncement on zakat on business is timely (MASB, 2006).

The purpose of accounting pronouncement for business zakat is to guide the treatment and disclosure for business zakat transaction (MASB, 2006). The issuance of MASB TR i-1 is indeed a very good progress towards a standardization of business zakat practices in Malaysia. It has recognized the methods proposed by JAKIM in the zakat guide book as the one to be used to calculate the business zakat in Malaysia (MASB, 2006). These are the net working capital and the net growth method. The methods can be calculated by manipulating the accounting equation, both yielding the same result (Ibrahim et al., 2012).

However, the MASB TR i-1 is just focusing on the accounting treatment and disclosure for business that make a zakat payment, not on the disclosure to assists in the business zakat 
computation. The pronouncement issued was also just a technical release, which does not have the compliance level as standard (Bakar, 2007; Ibrahim et al., 2012). Thus, there is still a limitation in accounting pronouncement with a gap between the accounting reporting and information needed for business zakat computation.

The issuance of MASB TR i-1 was an honour task done by MASB. With MASB TR i-1, accounting practitioners in Malaysia were more aware about their obligation towards business zakat. Although the MASB TR i-1 in its present form, is limited and cannot fully satisfy the need of zakat authorities to compute the business zakat (Abdul Rahman, 2007; Syed Adwam Wafa, 2006a), undeniably it was very good efforts. As time goes by, the weakness would be rectified. The objectives of accounting in Islam, which is to determine the zakatable base (Baydoun \& Willet, 1998; Mohamed Ibrahim, 2000) is still out there, to be work out and reached.

\section{Accounting for Business Zakat in Malaysia: The Way Forward}

For the way forward of accounting for business zakat in Malaysia, a standard accounting practice on zakat need to narrow the gap between the firms that pay zakat, and the zakat authorities who manage zakat, in term of the disclosure statement, the method of measurement, and the method of presenting data in financial statements (Abdul Rahman, 2007). Therefore, some kind of enforcement is required to minimize the differences between accounting disclosure and the information needed for zakat. This shall take a post-structural study, in which the current structural is used for further enhancement.

The post-structural can be referred to as the modification on the existing structure to meet the current environment (Koornhof \& Villiers, 1999). Since the issuance of MASB TR i-1 in 2006, there has been no major event to enhance the practices of business zakat. There was no major improvement on the methodology used, or the practice of accounting disclosure to facilitate the business zakat payment. Although there were studies done and suggestion made, yet there is no major change on the practicality of business zakat.

Among the studies done about the business zakat methods and accounting for business zakat disclosure in Malaysia are; Hamat (2011) on the alternate method on business zakat computation, Ahmad et al. (2013) and Sanep \& Othman (2010) on suggestions to improve the current methods, Rahman (2007) on the needs to standardise the zakat accounting practices and developing performance measure system, Bakar (2007) on the accounting for zakat practice in Malaysia and the needs for harmonisation, Adnan \& Bakar (2009) on suggestion for the accounting practices on business zakat, Abdulah et al. (2012) and Mohd Rizuan et al. (2013) on the MASB TR i1 practices by Malaysian listed companies, Bakar \& Rahman (2007) and Hamat (2009) about business zakat and its relation to accounting; Abdulah, Mohd Rizuan, \& Abdul Aziz (2013) on perception of practicality of MASB TR i1; Sarini \& Syed Mohd Ghazali (2011) on the relevancy to disclose Zakat Per Share (ZPS); Aznan (2013) on the issue of zakat payment by business at company level (legal entity existence and the concept of Khulta') and Abdul Hamid (2013) also the issue on zakat payment by business at company level from legal perspective.

Based on the studies on the development of accounting for business zakat in Malaysia, there is a crucial and urgent need to close the gap between the current accounting disclosures 
and information needed for business zakat computation. Since the current accounting disclosure cannot meet the demand of information for business zakat computation, the zakat conditions need to be reinterpreted to be in line with the accounting principles. This is to enable accounting disclosure reveal the needed information. At the same time, there is a need for an addendum in current accounting pronouncement as they failed to supply required information for business zakat computation. Thus, there is a need to harmonise the zakat conditions with accounting principles. A new disclosure for business zakat needs to be established by enhancing the current structures.

The efforts to close the gap between zakat and accounting practices, through a new disclosure can be considered as a post-structural study. It is not purely a post-structural as suggested (Merriam, 1998), but likewise of a post-structural (Koornhof \& Villiers, 1999). It involves a major modification through enhancement of existing structure. The suggested poststructural study to develop accounting disclosure that can meet the information for business zakat computation, is tabulates as in Figure 1.

Figure 1: The Way Forwards For Accounting for Zakat on Business

\begin{tabular}{|c|c|c|}
\hline $\begin{array}{l}\text { Modernisation } \\
\text { in Zakat }\end{array}$ & Structural Practices for Zakat on Business & The Post-Structural \\
\hline $\begin{array}{l}\text { - Privatisation of } \\
\text { zakat } \\
\text { institutions } \\
\text { - Fatwa on } \\
\text { Business Zakat }\end{array}$ & $\begin{array}{l}\text { - Pusat Zakat Selangor initiative proposing } \\
\text { methods for business zakat computation } \\
\text { - Issuance of guideline 'Panduan } \\
\text { Pengurusan Zakat di Malaysia' by } \\
\text { JAKIM } \\
\text { - Issuance of accounting pronouncement of } \\
\text { MASB TR i-1 } \\
\text { - Government recognition on business zakat }\end{array}$ & $\begin{array}{c}\text { A disclosure that } \\
\text { facilitate the business } \\
\text { zakat computation (by } \\
\text { harmonising zakat } \\
\text { conditions and } \\
\text { accounting principles) }\end{array}$ \\
\hline
\end{tabular}

In brief, current accounting disclosure has yet succeded in fulfilling the information needed, as mentioned in zakat conditions, for business zakat computation. Therefore, the zakat conditions needs to be harmonised with accounting principles, as so to produce a disclosure that can meet the requirement for business zakat computation purposes (Wafa, 2006). This shall be done through a thorough post-structural study.

\section{Conclusion: Harmonising Zakat Conditions and Accounting Principles}

The role of MASB TR i-1 is to guide the treatment and disclosure for business zakat payment (MASB, 2006). However, the pronouncement issued is just a technical release, which does not have the compliance level as standard (Bakar, 2007; Ibrahim et al., 2012). The scope of MASB also limited to the companies that make the zakat payment (Ibrahim et al., 2013). Therefore, 
present accounting disclosure still does not recognised the needs of information to facilitate the business zakat payment (Rahman, 2007; Wafa, 2006a).

The limitation, MASB TR i-1 has succeded in narrowing the gap between the accounting reporting and information needed for business zakat computation. The current financial accounting disclosure, in its present form, cannot fully satisfy the zakat authorities to compute the business zakat (Rahman, 2007; Wafa, 2006a). Thus, the objectives of accounting in Islam, which is to determine the zakatable base (Baydoun \& Willet, 1998; Ibrahim, 2000) is still out of reach (Bakar, 2007).

Rahman (2003) suggested that among the areas that need to be narrowed down are the disclosure statement, the method of measurement, and the method of presenting data in financial statements. Business zakat computation requires some financial information about the business assets, which is within the ambit of accounting reporting. But some information required for zakat is further specified by Shariah, which is beyond the scope of accounting reporting.

This paper suggests that the zakat conditions need to be harmonised with accounting principles. Guided by Shariah, zakat conditions need to be reinterpreted, for it to be reached by accounting disclosure. At the same time, accounting principles need to be flexible enough in order to meet the demand of information for business zakat computation. This harmonisation process shall close the gap between information needed for zakat information and current accounting disclosure practices. Thus, harmonising zakat conditions and accounting principles is very important to facilitate the business zakat computation. It is suggested that harmonisation to be made to close the gap is done in the way as shown in Figure 2 below.

Figure 2: Harmonising Zakat Conditions with Accounting Standards

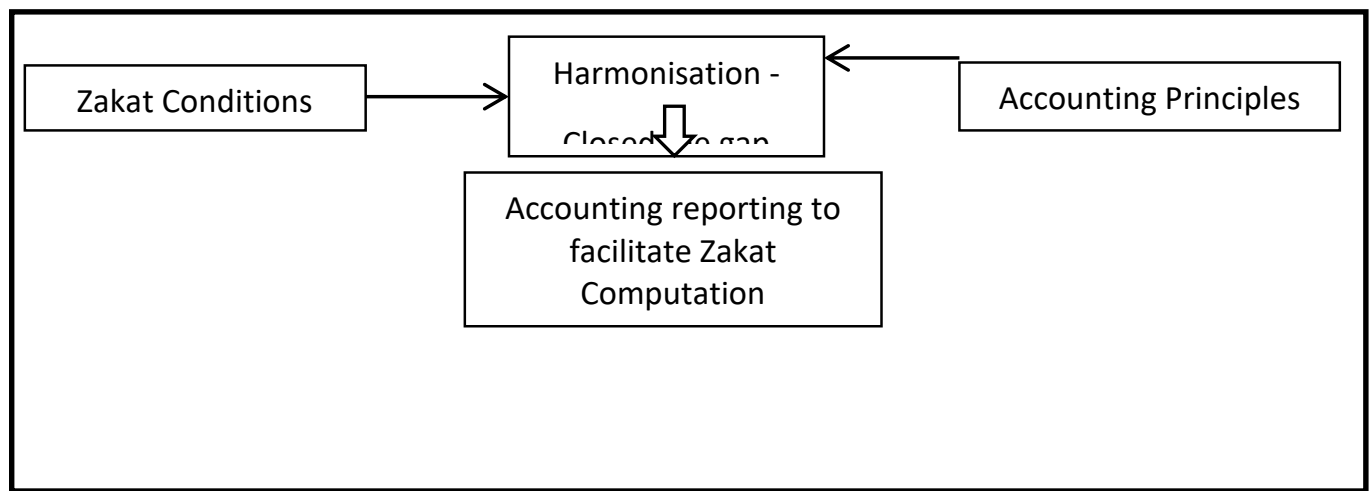

Based on the current structure issued by the zakat authorities and MASB, it can be said that the efforts of using accounting to facilitate the business zakat payment has been started, but yet finished. Initiated by Pusat Zakat Selangor in 1999 (Lembaga Zakat Selangor, 2007) and ended with MASB recognition on accounting pronouncement for business zakat in 2006 (MASB, 2006). The efforts need continuation to ensure accounting reporting can really serve the need of information for business zakat computation. 
INTERNATIONAL JOURNAL OF ACADEMIC RESEARCH IN BUSINESS AND SOCIAL SCIENCES

Vol. 9, No. 11, November, 2019, E-ISSN: 2222-6990 @ 2019 HRMARS

\section{Acknowledgements}

This paper is supported by Fundamental Research Grant (FRGS) awarded by the Ministry of Education, Malaysia. Ref Project Code: RR019.

\section{References}

Rahman, A., Alias, M., \& Najib, S. O. (2012). Zakat Institution in Malaysia : Problems and Issues. GJAT, 2(1), 35-42.

Hamid, M. (2013). Obligation of Companies to Pay Zakat: Issues Arising From Effects of Separate Legal Entity. Kuala Lumpur.

Kadir, M. R., Ramli, J. A., Abidin, Z., \& Surbaini, K. N. (2013). Malaysian Public Listed Companies Practiced on Zakat Disclosure. In National Symposium \& Exhibition on Business \& Accounting 2013.

Rahman, A. R. (2007). Pre-requisites for Effective Integration of Zakah into Mainstream Islamic Financial System in Malaysia. Islamic Economic Studies, 14(1), 91-107.

Abu-Ubayd, S. (2007). The Book of Finance. (G. Noor Mohammad, Ed.). New Delhi: Adam Publishers \& Distributors.

Bakar, N. B. (2007). A Zakat Accounting Standard (ZAS ) for Malaysian Companies. The American Journal of Islamic Social Sciences, 24(4), 74-95.

Adnan, M. A., \& Bakar, N. B. (2009). Accounting treatment for corporate zakat: a critical review. International Journal of Islamic and Middle Eastern Finance and Management, 2(1), 32-45. http://doi.org/10.1108/17538390910946258

Ahmad, M. S. (2006). Penentu Hukum Syarak dalam Taksiran Zakat Perniagaan. In I. Abdul Ghafar \& H. M. Tahir (Eds.), Zakat Pensyariatan Perekonomian dan Perundangan (1st ed.). Bangi: Universiti Kebangsaan Malaysia.

Ahmad, O., Adnan, A. A., \& The, K. S. (2013). Penilaian Semula Dividen, Pembelian Aset Modal Dan Derma Dalam Taksiran Zakat Perniagaan Korporat Bagi Tujuan Penyeragaman Nilai Taksiran Zakat. In 2nd International Management Coference 2013 (pp. 1-11). Kuala Terengganu.

Ahmad, S., \& Ahmad, O. (2010). Penilaian Semula Taksiran Zakat. Jurnal Syariah, 18(3), 565-584.

Al Qaradawi, D. Y. (2011). Figh al zakah (Vol. 1) A Comparative Study of Zakah, Regulations and Philosophy in The Light of Qur'an and Sunnah. (I. Siddiqui, Ed.). Petaling Jaya: Islamic Book Trust.

Azizan, S., \& Wafa, S. M. G. W. (2011). Preliminary Evaluation of Zakat Disclosure and Zakat Per Share Analysis. In The World Universities 1st Zakat Conference.

Bahrom, H., \& Yaakub, E. (2007). Pengurusan zakat semasa (1st ed.). Shah Alam: Universiti Teknologi Mara.

Baydoun, N., \& Willet, R. (1998). Islamic Corporate Reports: The Shariah, Islamic banks and Accounting Concepts and Practices. In Proceedings of International Conference 1: Acounting, Commerce and Finance: the Islamic Perspective. Sydney, Australia: University of Western Sydney.

E-Fatwa. (2009). Himpunan Keputusan Muzakarah Jawatankuasa Kebangsaan: Berhubung 
INTERNATIONAL JOURNAL OF ACADEMIC RESEARCH IN BUSINESS AND SOCIAL SCIENCES

Vol. 9, No. 11, November, 2019, E-ISSN: 2222-6990 @ 2019 HRMARS

Dengan Isu-Isu Muamalat- Zakat Ke Atas Syarikat. Retrieved from www.efatwa.gov.my/fatwa-kebangsaan/zakat-ke-atas-syarikat.

Hamat, Z. (2007). Perakauan Zakat Perniagaan di Malaysia: satu Kajian Rintis Pendapat Cendekiawan Zakat. In TESIS PHD. Retrieved from http://eprints.usm.my/8264/1.pdf

Hamat, Z. (2009). Business Zakat Accounting and Taxation. In Islamic Perspectives on Management and Finance (pp. 13-18).

Hussaini, U., Bakar, A.A., Yusuf, M.-B., O. (2018). The Effect of Fraud Risk Management, Risk Culture, on the Performance of Nigerian Banking Sector: Preliminary Analysis, International Journal of Academic Research inAccounting, Finance and Management Sciences 8 (3): 224237

Hamat, Z. (2011). Perubahan Dalam Perakaunan Zakat di Malaysia. Jurnal Pengurusan Jawhar, 5(1), 19-33.

Rushd, I. (1994). The Distinguished Jurist's Premer. (A. K. Nyazee, Ed.) (1st ed.). Reading: Garnet. Ibrahim, A. (1997). Zakat: Beberapa Masalah Semasa Dan Penyelesaiannya (1st ed.). Kelantan: Pustaka Reka.

Ibrahim, A., Kadir, M. R., \& Aziz, A. (2012). Assessing Financial Reporting on adopting Business Zakat Guidelines on Malaysian Government Linked Companies. International Journal of Business and Social Science, 3(24), 220-229.

Ibrahim, A., Kadir, M. R., \& Aziz, A. (2013). Perception of Accounting Practitioners on MASB TR i1. International Journal of Humanities and Social Science, 3(2), 247-253.

Ismail, A. G., \& Azura, S. (2006). Perluasan Kewajipan Berzakat, Jaminan Social dan Desentralisasi Fiskal. In I. Abdul Ghafar \& T. Hailani Muji (Eds.), Zakat Pensyariatan Perekonomian dan Perundangan (1st ed., pp. 95-100). Bangi: Universiti Kebangsaan Malaysia.

Koornhof, C., \& Villiers, C. (1999). Postmodernism and accounting : Mirror or myth ? Meditari Accountancy Research, 7, 145-164.

Mahamood, S. M. (2007). Sistem Perundangan Zakat Di Malaysia: Antara Realiti dan Harapan. In Persidangan Zakat Dan Cukai Peringkat Kebangsaan (p. 1.22). Kuala Lumpur.

MASB. (2006). Accounting for Zakat on Business. Kuala Lumpur: Malaysian Accounting Standard Board.

Means, G. P. (2006). The Role of Islam in the Political Development of Malaysia. In T. Storch (Ed.), Religions and Missionaries around the Pacific, 1500-1900 (1st ed.). Farnham: Ashgate Publishing.

Merriam, S. B. (1998). Qualitative Research and Case Study Applications in Educations. San Francisco: Jossey-Bass.

Ibrahim, S. H. (2000). The Need for Islamic Accounting; Perceptions of Its Objectives and Characteristics by Malaysian Muslim Accountants and Accounting Academics. University of Dundee.

Rais, A. (2013). Zakat: A Catalyst in Promoting Ummah's Development: A Malaysian Experience. Jurnal Pengurusan Jawhar, 7(2), 65-110.

Mustapha, M. Z., \& Sapiei, N. S. (2007). A Comparative Study of Zakah and Modern Taxation. J.KAU: Islamic Econ., 20(1), 25-40. 
Mansor, M., Yusof, H., Yusof, R., Norwani, N. M., Jalil, N. A., Yuet, F. K. C., ... Musa, K. (2018). Teacher Leadership Factors and Teacher Leadership Model Based on the Six Guiding Principles. International Journal of Academic Research in Progressive Education and Development, 7(4), 468-487.

Norita, M. N., \& Salleh, H. (2005). Zakat on Business in Malaysia: Issues and Current Treatment. In B. Shanmugam, V. Perumal, \& R. Alfieya Hanuum (Eds.), Issues in Islamic Accounting (1st ed.). Serdang: Universiti Putra Malaysia.

Wafa, S. M. G. W. (2006a). Harmonisation of Conditions of Zakat Accounting into the Accounting Reporting Framework.

Wafa, S. M. G. W. (2006b). Kajian Perbandingan Syarat-syarat Penaksiran Zakat Perniagaan Malaysia dengan FAS 9 AAOIFI. In Zakat Pensyariatan Perekonomian dan Perundangan (1st ed.). Kuala Lumpur: Universiti Kebangsaan Malaysia.

Wahid, H., Ahmad, S., \& Kader, R. (2008). Pengagihan Zakat Oleh Institusi Zakat Di Malaysia: Mengapa Masyarakat Islam Tidak Berpuas Hati. In Seminar Kebangsaan Ekonomi Malaysia (pp. 804-816). 